\title{
THE INTERNATIONAL CRIMINAL COURT AND The Cases of Muammar Al-Gaddafi, SAIf Al-Islam GADDAFI AND ABDULlaH AL-SENUSSI
}

\author{
RÚBIA MARCUSSI PONTES ${ }^{\dagger}$ \\ LEONARDO FARIA ${ }^{\dagger \dagger}$
}

\begin{abstract}
The International Criminal Court (ICC) is the international organization created through the Rome Statute in order to judge the main international cases of crimes that are under its jurisdiction. Even tough is an in independent organization and therefore not a part of the United Nations (UN) system, it is strictly related to the United Nations Security Council (UNSC), who has addressed the situation in Libya to the Court in 2011 through the Resolution 1970. From that moment on, the ICC analyzed the cases of Muammar Al-Gaddafi, Saif Al-Islam Gaddafi and Abdullah Al-Senussi, who were high authorities in the previous Libyan regime. Therefore, this article aims to demonstrate the context of creation of the International Criminal Court and the forces involved on it as well as the situation in Libya and how the judgment of its formers leaders were related to the ICC. The focus is to highlight the importance of the Court and to analyze its capability of fulfilling its objectives in nowadays-international system specifically in the observance of the cases in study.
\end{abstract}

KEYWORDS: International Criminal Court; United Nations Security Council; North Atlantic Treaty Organization; Libya; War Crimes.

\footnotetext{
Graduate in Foreign Relations, with focus on Foreign Policy and International Politics, Faculdades de Campinas, Brazil.

${ }^{\dagger}$ Graduate student in Foreign Relations, with focus on Foreign Policy, Faculdades de Campinas, Brazil.
} 
ResUMO: O Tribunal Penal Internacional (TPI) é a organização internacional criada pelo Estatuto de Roma a fim de julgar os principais casos internacionais de crimes que estão sob sua jurisdição. Ainda que seja uma organização independente e, portanto, não uma parte do sistema das Nações Unidas (ONU), está diretamente relacionado com o Conselho de Segurança das Nações Unidas (CSNU), que conduziu a situação da Líbia à Corte em 2011 por meio da Resolução 1970. A partir de então, o TPI analisou os casos de Muammar Al-Gaddafi, Saif AlIslam Gaddafi e Abdullah Al-Senussi, que eram altas autoridades do anterior regime líbio. Assim, este artigo visa demonstrar o contexto de criação do TPI e as forças envolvidas nesse processo, bem como a situação na Líbia e como o julgamento de seus ex-líderes estava relacionado com o TPI. O objetivo é analisar a importância da Corte e analisar sua capacidade de atender a seus propósitos no atual sistema internacional, especificamente com observância dos casos estudados.

Palavras-Chave: Tribunal Penal Internacional; Conselho de Segurança das Nações Unidas; Organização do Tratado do Atlântico Norte; Líbia; Crimes de Guerra. 


\section{TABLE OF CONTENTS:}

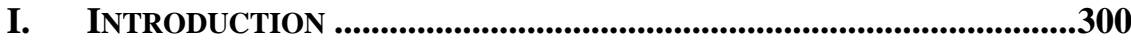

II. ThE INTERNATIONAL CRIMINAL COURT ........................................301

1. The Rome Conference: the negotiations ...........................304

2. The Rome Statute and the Jurisdiction of ICC.................306

III. THE CONFLICT IN LIBYA ..............................................................310

1. A Historical Overview ...........................................................310

2. Gaddafi's government, the $P-5$ and the UNSC..................313

3. NATO's actions .................................................................316

IV. FINAL CONSIDERATIONS ............................................................318

V. REFERENCES ........................................................................323

\section{SUMÁRIO:}

I. INTRODUÇÃ

II. O TRIBUNAL PENAL INTERNACIONAL .......................................301

1. A Conferência de Roma: as negociações...........................304

2. O Estatuto de Roma e a Jurisdição do TPI ........................306

III. O CONFLITO NA LÍBIA ....................................................................310

1. Uma Panorâmica Histórica .....................................................310

2. Governo de Gaddafi, o P-5 e o CSNU ..................................313

3. Ações da OTAN.....................................................................316

IV. CONSIDERAÇÕES FINAIS.......................................................318

V. REFERENCIAS .......................................................................323 


\section{INTRODUCTION}

The uprisings and popular manifestations that led to the called Arab Spring in the 2010s are key events to understand the paths that the international system has taken since then. The main claims during the uprisings were the end of autocratic regimes that had been in power for decades in some North African and Middle East countries and the instauration of democracies.

However, the reality of the uprisings was more complex than it appeared to be: the Libyan case is only one example in a series of events that have caused an impact in the region, bringing delicate situations that are still going on. The international community, regarding the exponential rise of violence and the violation of international law, has started to take action in order to prevent the aggravation of the situation. The United Nations Security Council (UNSC) and the North Atlantic Treaty Organization (NATO) are two iconic international organizations that have taken actions in order to control the situation mainly through military actions.

Moreover, regarding the incredible violation of human rights during the Arab Spring, legal action also had to be adopted to judge particular cases and individuals that have been part of the process. That being said, it is crucial to highlight the importance of the International Criminal Court (ICC) which is the sphere par excellence in the international system that can prosecute crimes such as genocide, crimes against humanity, war crimes and crimes of aggression. ${ }^{1}$ The ICC, created in 1998 through the Rome Statute, is considered the most innovative development in international law since the creation of the United Nations (UN), due to its high level of application of the international law in a more attainable standard and its capability of judging individuals who are submitted to its jurisdiction.

The implications of the Arab Spring in Libya are, therefore, essential to the ICC judgment of Muammar Al-Gaddafi, Libyan Head of State and commander of the Armed Forces; Saif Al-Islam Gaddafi, Libyan de facto Prime Minister; and Abdullah Al-Senussi, Libyan Head of Military Intelligence. The main purpose of this article is to present, in the first place, the process of creation of the ICC and the negotiations that led to the approval of the Rome Statute in 1998. Then, the escalation of the

${ }^{1}$ See International Criminal Court, About the Court, in OfFicial WeBsite OF THE INTERNATIONAL CRIMINAL COURT (2014), available at $<$ http://www.icccpi.int/en menus/icc/about $\% 20$ the $\% 20$ court/Pages/about $\% 20$ the $\% 20$ court.aspx>. 
conflict in Libya in 2011 will be analyzed bearing in mind the historical background that led to the conflict itself and the ICC's role in the judgment of the defendants. Finally, the final considerations will highlight some aspects that were dealt with in the recent events concerning the judgment of the defendants. The main objective is to emphasize the importance of the Court in nowadays-international system and to analyze its capability of fulfilling its objectives specifically in the cases of Muammar Al-Gaddafi, Saif Al-Islam Gaddaffi and Abdullah Al-Senussi.

\section{The INTERNATIONAL CRIMINAL COURT}

The international system, based on the interaction among States, has been marked by initiatives that tried to impose certain obligations to them especially in matters related to war. These initiatives are known as international treaties and, since 1872, proposals for the creation of a permanent international court to handle with the growing violations of human rights have gained projection. However, the codification of laws was not enough to guarantee peace in the international system. The First (1914-1919) and the Second World Wars (1939-1945) were the apex of violence and cruelty. Although the intention of creating an international court was to analyze the crimes of war that arose after the $\mathrm{WWI}^{2}$, it was only after the Nazism and the deep consequences of the Second War that it has become a reality through the foundation of the UN and its General Assembly Resolution 96, of 11 December 1946, which declared genocide as a crime against international law. ${ }^{3}$

Moreover, the individual responsibility in war was also codified through the work of the International Law Commission (ILC), related to the United Nations General Assembly (UNGA). However, even though the ILC and the UNGA worked closely during the second half of the XX

\footnotetext{
2 In 1937, the International Law Association and the International Association of Penal Law succeed in creating an international criminal court, which would be effective through the League of Nations' treaty. However, the required number of ratifying States was not reached and, therefore, the initiative did not turn into reality. See WILLIAM SCHABAS, AN INTRODUCTION TO THE INTERNATIONAL CRIMINAL COURT (2004), pp. 5.

3 See William Schabas, AN INTRODUCTION tO THE INTERNATIONAL CRIMINAL COURT (2004), pp. 5-7.
} 
century, the context of Cold War and the constant struggle for power between the United States of America (USA) and the Union of the Soviet Socialist Republics (USSR) caused a certain inertia in the UNSC, responsible for dealing with threats to international peace and security. With the end of the Cold War and with the transformations that followed the breakdown of the Berlin Wall, the collapse of the USSR and the new types of conflicts, the scenario changed. ${ }^{4}$

The genocides in Yugoslavia and Rwanda are iconic cases of the period and the brutalities committed in those countries shocked the international public opinion and led to the creation of ad hoc tribunals that would judge these specific cases. The results were the International Criminal Tribunal for the former Yugoslavia (ICTY), in 1993, and the International Criminal Tribunal for Rwanda (ICTR), in 1994, which were mandated by the UNSC, whose power had increased in comparison with the former period. ${ }^{5}$ Nevertheless, the specific pre-determined nature of these ad hoc committees was not enough in a world marked by constant conflicts. The international community, after decades of briefing, had to definitely create an international court capable of judging individuals who committed war crimes.

The ICC, created in 1998, was, therefore, "the first permanent, treaty based, international criminal court established to help end impunity for the perpetrators of the most serious crimes of concern to the international community". ${ }^{6}$ Its headquarters are at The Hague, the Netherlands' capital. The Court counts with eighteen judges who are responsible for the trials, as well as the Presidency, the Office of the Prosecutor, the Registry and other Offices, such as the Office of Public Counsel for Victims. The main functions of crucial spheres in the ICC will be demonstrated below.

The ICC counts with a Presidency based on three judges, being one President and two Vice-Presidents, who are elected for a three-year renewable term. Three Divisions compose the ICC: the Appeals Division, the Trial Division and the Pre-Trial Division, which are divided by Chambers that carry out the judicial functions. All the

4 See Elio Cardoso, Tribunal PenAl InTERnACIONAL: CONCEITOS, REALIDADES E

IMPLICAÇÕES PARA O BRASIL (2012), pp. 23-24.

5 See Elio Cardoso, Tribunal PenAl InTERnACIONAL: CONCEITOS, REALIDAdES E IMPLICAÇÕES PARA O BRASIL (2012), pp. 26.

6 See International Criminal Court, About the Court, in OfFicial Website Of THE INTERNATIONAL CRIMINAL COURT (2014), available at $<$ http://www.icccpi.int/en menus/icc/about\%20the\%20court/Pages/about\%20the\%20court.aspx>. 
Divisions count with judges that are elected to the Court "in such a way that each division shall contain an appropriate combination of expertise in criminal law and procedure and in international law". ${ }^{7}$ The judges in the ICC are all advocates, prosecutors or judges internationally known by their work with international humanitarian and human rights laws, as well as their expertise in criminal proceedings. ${ }^{8}$

The Prosecutor and the Deputy Prosecutor, who are responsible for the investigation and the accusation of the defendants, compose the Office of the Prosecutor. The Office "investigates and prosecutes genocide, crimes against humanity and war crimes committed by nationals of a State party or on the territory of a State party". ${ }^{9}$ There are also three departments that compose the Office, which are the Investigations Division, the Jurisdiction, Complementarity and Cooperation Division and the Prosecutions Division.

The Defense is essential in the ICC administration and was conceived in the Rome Statute in its Article 67. This instance allows "the ground for excluding criminal responsibility and the presumption of innocence".$^{10}$ Therefore, the Defense, composed by renowned lawyers chosen by the Court, represents the defendants and their rights to an impartial and fair judgment. The representatives of the Defense usually are international advocates or judges that have an extensive knowledge of international law and politics as well as a profound knowledge of the ICC proceedings.

Finally, the "Legal Representatives of the Victims (LRV) is the term used to define the counsel who is allowed to work at the ICC and is in

7 See International Criminal Court, Chambers, in OfFICIAL WeBSITE OF THE

INTERNATIONAL CRIMINAL COURT (2014), available at $<$ http://www.icc-

cpi.int/en menus/icc/structure $\% 20$ of $\% 20$ the $\% 20$ court/chambers/Pages/chambers.aspx>

8 See International Criminal Court, Structure of the Court, in OfFICIAL WeBSITE OF THE

INTERNATIONAL CRIMINAL COURT (2014), available at $<$ http://www.icc-

cpi.int/en menus/icc/structure $\% 20$ of $\% 20$ the $\% 20$ court/Pages/structure $\% 20$ of $\% 20$ the $\% 2$

0court.aspx>.

${ }^{9}$ See International Criminal Court, Office of the Prosecutor, in OfFICIAL WEBSITE OF THE

INTERNATIONAL CRIMINAL COURT (2014), available at $<$ http://www.icc-

cpi.int/en menus/icc/structure $\% 20$ of $\% 20$ the $\% 20$ court/office $\% 20$ of $\% 20$ the $\% 20$ prosecuto r/Pages/office\%20of\%20the\%20prosecutor.aspx>.

10 See International Criminal Court, Defence, in OfFICIAL WEBSITE OF THE INTERNATIONAL CRIMINAL COURT (2014), available at $<$ http://www.icc-

cpi.int/en menus/icc/structure $\% 20$ of $\% 20$ the $\% 20$ court/defence/Pages/defence.aspx $>$. 
charge of presenting the 'views and concerns' of victims before the Court" (TISERRANT, 2013). ${ }^{11}$ Since its creation, the ICC has valued a strong voice of the victims in the trials; therefore, the LRV has a key role in guarantying the fairness of the proceedings. The victims' legal representative must have an extensive experience with criminal law and be a judge or a prosecutor in order to be able to occupy this office. ${ }^{12}$

Even though the creation of the ICC was a growing demand from the international community in the 1990s, it is possible to affirm that its process of constitution was not an easy task. Before its creation, the ICC was submitted to a long process of negotiations and bargain amongst States in order to establish a statute draft that was submitted to the UNGA in 1994. After years of negotiation, the ILC project had suffered several changes, but was finally condensed in what would be called the Rome Statute ${ }^{13}$, which was discussed in the Rome Conference and is analyzed in the following topic.

\section{The Rome Conference: the negotiations}

As previously noted, the creation of a permanent international court went through a complicated process until it was finally established in 1998. The UNGA, in coordination with the ILC, created an $\mathrm{Ad} \mathrm{Hoc}$ Committee that gathered twice in 1995 in order to elaborate a draft of a statute. However, since this part of negotiations, “(...) debates within the Ad Hoc Committee revealed rather profound differences among States about the complexion of the future court". ${ }^{14}$ The negotiation process evolved through the years, but some States initially demonstrated a certain resistance and precaution with the idea,

\footnotetext{
${ }^{11}$ See Claire Tisserant, Victims' participation at the International Criminal Court (ICC): the growing role of their legal representatives, in INTERNATIONAL JUSTICE PROJECT, August, 8, 2013, available at $<$ http://www.internationaljusticeproject.com/victims-participation-atthe-international-criminal-court-icc-the-growing-role-of-their-legal-representatives/>. 12 See International Criminal Court, Legal Representatives of Victims, in OFFICIAL WEBSITE OF THE INTERNATIONAL CRIMINAL COURT (2014), available at $<$ http://www.icccpi.int/en menus/icc/structure $\% 20$ of $\% 20$ the $\% 20$ court/victims/legal\%20representation/ Pages/legal\%20representatives\%20of\%20victims.aspx>.

${ }^{13}$ See Elio Cardoso, TRIBUnal Penal InTERnaCiOnAL: CONCEITOS, REALIDADES E IMPLICAÇÕES PARA O BRASIL (2012), pp. 34-36.

14 See WiLLIAM SCHABAS, AN INTRODUCTION TO THE INTERNATIONAL CRIMINAL COURT (2004), pp. 13.
}

1 JOURNAL OF INSTITUTIONAL STUDIES 1 (2015) 
especially the permanent members of the UNSC (USA, United Kingdom, France, China and Russia). However, over time, they have changed their posture: they began to accept the fact that an international court would be established, but this would not happen without certain safeguards imposed by them through the UNSC. ${ }^{15}$

After six sessions of the UNGA, from 1996 to 1998, the Rome Statute was finally ready for approval. The new court would only recognize and accept cases for judgment when "national justice systems were unwilling or unable to try them". ${ }^{16}$ The preservation of national courts' jurisdiction was an example of the power from the permanent members of the UNSC in the elaboration of the document. The Diplomatic Conference of Plenipotentiaries on the Establishment of an International Criminal Court, which had been established for the final vote of the Statute of the new ICC, convened on 15 June 1998, in Rome, at the headquarters of the Food and Agriculture Organization (FAO), with extensive participation of States, non-governmental organizations and other actors. ${ }^{17}$

At the Conference, two new groups were formed during the final debates: the "like-minded group" and the "P-5". The first was led by Canada and was composed by developing countries and middle powers. They defended an ICC that would have an independent juridical personality. The second group, formed by the permanent members of the UNSC, with the exception of the United Kingdom, which had joined the "like-minded group", tried to reinforce their power in the new ICC through a major presence of the UNSC in the establishment of the Court; therefore, their project was clearly one in which the Court's jurisdiction would be limited by the UNSC referrals, a prerogative that was intensely defended by the USA. The Conference, however, counted with more working groups: the Non-Aligned Movement (NAM) and the Southern African Development Community (SADC), groups that insisted, for example, in the inclusion of the crime of aggression within the Court's jurisdiction. ${ }^{18}$

${ }^{15}$ See Elio Cardoso, Tribunal Penal InTERnacional: CONCEITOS, REALIDAdes E IMPLICAÇÕES PARA O BRASIL (2012), pp. 36.

${ }^{16}$ See WiLliam SCHABAS, AN INTRODUCTION TO THE INTERNATIONAL CRIMINAL COURT (2004), pp. 15.

17 See WiLliam Schabas, AN INTRODUCTION TO THE INTERNATIONAL CRIMINAL COURT (2004), pp. 15.

18 See WiLliam SCHABAS, AN INTRODUCTION TO THE INTERNATIONAL CRIMINAL COURT (2004), pp. 16-17. 
The Conference continued, but all the working groups avoided critical points, such as the jurisdiction of the Court over crimes. The chair of the Conference, Philippe Kirsch, seeing that the days of the gathering were coming to an end, made a package that was submitted to vote on the last day of the Conference. After some tensions, by a final vote of 120 in favor, 21 abstaining and 7 against, the Rome Statute was approved, creating the ICC. The USA, China, Iraq, Israel, Libya, Qatar and Yemen voted against the Statute, mainly due to the power conferred to an independent prosecutor of the Court. ${ }^{19}$

\section{The Rome Statute and the Jurisdiction of ICC}

After the approval of the Rome Statue, its ratification was the next important step, as States would only be subject to ICC's jurisdiction after incorporating the Statue to their internal systems of laws. Therefore, to entry into force, the Rome Statute required at least sixty ratifications to start the formalities of establishing the Court and electing its judges and its Prosecutor. Even with the adoption of the Rome Statute by 120 countries, in 1998, it was only in 2002 that 60 countries ratified it, thus the Statute only entered into force on 1 July 2002. Since then, 121 States ratified the Rome Statute.

From this moment on, the ICC had power to exercise its jurisdiction over persons for the most serious crimes. The ICC was created based on the principle of complementarity, meaning that the Court's work was complementary to that of national jurisdictions: even though the Court is an independent international organization, the States must choose to be subject to it. ${ }^{20}$ Therefore, it is important to highlight the relevance of Article 5 from the Rome Statute, which disposes about the ICC's jurisdiction and lists the most serious and significant international crimes that could be judged by the Court. The jurisdiction of the ICC is over four types of crime: the crime of genocide, crimes against humanity, war crimes and the crime of aggression. ${ }^{21}$

19 See William SCHABAS, AN INTRODUCTION TO THE INTERNATIONAL CRIMINAL COURT (2004), pp. 17.

20 See Elio Cardoso, Tribunal Penal Internacional: CONCEITOS, REAlidades E IMPLICAÇÕES PARA O BRASIL (2012), pp. 42-46.

${ }^{21} \mathrm{See}$ Valerio de Oliveira MaZZuOl, Tribunal Penal InTERnacional e O Direito BRASILEIRO (2011), pp. 51. 
The definition of genocide has been included in the debate over international law especially after the Nuremberg trial. The Convention on the Prevention and Punishment of the Crime of Genocide, adopted by the UNGA on 1948, was a considerable advance and essential to the Rome Statute, which, being inspired by the Convention, defines in its Article 6 that the crime of genocide is related to "(...) specific acts committed with the intent to destroy a national, ethnical, racial or religious group".$^{22}$ Any attempt to murder or harm any member of a group is considered genocide, as well as any attempt to destroy the group or its members through certain conditions of life. The specificity of this crime is that the perpetrator of the act has a clear intention, which is to destroy a group through physical, biological or cultural means. The classification of this crime was not an easy task, especially when taking into consideration the possibility of cultural genocide, which means that the suppression of a national language can be seen as an act of genocide. ${ }^{23}$

The Article 7, in turn, is related to the crimes against humanity and any attempt of attack, direct or not, against any civilian group with the intention of extermination, enslavement or imprisonment. ${ }^{24}$ The definition of crimes against humanity varied over time and it is important to highlight that some of these definitions did not consider the existence of an armed conflict: therefore, a crime against humanity could happen without an ongoing armed conflict. However, changes occurred when the UNSC established the ICTY in 1993: the Statute of that Tribunal only considered crimes against humanity those related to an armed conflict (whether international or within one State). Even though at the Rwanda Court, the UNSC did not insist upon the nexus, it is evident that the definition of crimes against humanity has a

\footnotetext{
22 See, International Criminal Court, Rome Statute of the International Criminal Court, in OFFICIAL WEBSITE OF THE INTERNATIONAL CRIMINAL COURT (2014), pp. 3, available at http://www.icc-cpi.int/NR/rdonlyres/ADD16852-AEE9-4757-ABE79CDC7CF02886/283503/RomeStatutEng1.pdf $>$.

${ }^{23}$ See William Schabas, AN INTRODUCTION TO THE INTERNATIONAL CRIMINAL COURT (2004), pp. 37-38.

${ }^{24}$ See, International Criminal Court, Rome Statute of the International Criminal Court, in OFFICIAL WEBSITE OF THE INTERNATIONAL CRIMINAL COURT (2014), pp. 3-5, available at http://www.icc-cpi.int/NR/rdonlyres/ADD16852-AEE9-4757-ABE79CDC7CF02886/283503/RomeStatutEng1.pdf>.
} 
controversial history. In the Rome Statute, the idea that crimes against humanity can happen with or without an armed conflict prevailed. ${ }^{25}$

In the jurisdiction of the ICC through the Rome Statute, it is possible to observe that war crimes are the oldest of the four categories. Article 8, which defines these crimes, was also one of the most controversial: the USA, for instance, believed that the ICC should only take jurisdiction over war crimes committed in a systematic way. Nevertheless, most members of the Conference understood that the definition had to contemplate the possibility of judgment of isolated cases, "in particular when committed as part of a plan or policy or as a part of a large-scale commission of such crimes". ${ }^{26}$ The definition of war crimes, therefore, became central in the Rome Statute, and acts such as torture, taking of hostages and depriving a prisoner of war of a fair trial, were included in the final definition of war crimes. The Article also differentiates international armed conflict from non-international armed conflict, which makes it even more difficult to the Court to judge cases, since nowadays the distinction is especially complicated. ${ }^{27}$

The crime of aggression, established in Article 8, in accordance with the United Nations Charter, defined that any use of force by a State against the sovereignty and the political integrity of another State would be considered a crime of aggression; invasion and annexation of another State via military force are also examples, as well as the sending of mercenaries or armed groups by one State against another. ${ }^{28}$ This category of crime was also subject of disagreement among States in the Rome Conference and it was not included in the final document: this was considered "an inadmissible regress" by many countries, once the

\footnotetext{
${ }^{25}$ See Elio Cardoso, Tribunal Penal InTERnacional: CONCEITOS, REALIDAdeS E IMPLICAÇÕES PARA O BRASIL (2012), pp. 49.

${ }^{26}$ See, International Criminal Court, Rome Statute of the International Criminal Court, in OFFICIAL WEBSITE OF THE INTERNATIONAL CRIMINAL COURT (2014), pp. 5, available at http://www.icc-cpi.int/NR/rdonlyres/ADD16852-AEE9-4757-ABE79CDC7CF02886/283503/RomeStatutEng1.pdf $>$.

${ }^{27}$ See WiLliam SCHABAS, AN INTRODUCTION TO THE INTERNATIONAL CRIMINAL COURT (2004), pp. 54.

${ }^{28}$ See, International Criminal Court, Rome Statute of the International Criminal Court, in OFFICIAL WEBSITE OF THE INTERNATIONAL CRIMINAL COURT (2014), pp. 9, available at http://www.icc-cpi.int/NR/rdonlyres/ADD16852-AEE9-4757-ABE79CDC7CF02886/283503/RomeStatutEng1.pdf>.
} 
crime was present in the Nuremberg Charter as "crime against peace". ${ }^{29}$ The definition of crime of aggression was only inserted in the Rome Statute by the resolution RC-Res.6 from 11 June 2010.

Taking into consideration the four types of crimes that the ICC has jurisdiction over, it is also important to highlight that "the International Criminal Court will also have jurisdiction over nationals of a State party who are accused of a crime" ${ }^{30}$ The only instance that could prevent the Court from exercising its power is the UNSC. The negotiations in the Rome Conference led to a "point of balance" between the main function of the Council to maintain the international peace and security and the ICC's autonomy. The leading decision was that the Council could "regularly discuss issues and themes relevant to the mandate and activities of the Court"31 and that the UNSC could request the suspension of any case submitted to the ICC; these measures were included in the Rome Statute through Article 16.

It is also important to expose the capacity of judgment of the ICC through the Rome Statute. It was defined that only individuals from States that ratified the Rome Statute can be subject to the jurisdiction of the ICC, unless the UNSC, under Article 7 of the United Nations Charter, refers a case to the ICC through the classification of violation of human rights that occurred in the territory of non-State party in the Rome Statute. These devices made the Statute a text subject to different interpretations due to the strategic abstention from three of the five permanent members of the UNSC: USA, China and Russia did not signed the document.

This means that they do not fall under the ICC's jurisdiction but can still exercise the power of veto in the UNSC. It demonstrates that, although the ICC was created by other countries' demands, the P-5 mainly USA, China and Russia - define the level of autonomy of the Court as they have done in the UN since its creation. ${ }^{32}$ Therefore, it is a

29 See Elio CARDOSO, TRIBUNAL PENAL INTERNACIONAL: CONCEITOS, REALIDADES E

IMPLICAÇÕES PARA O BRASIL (2012), pp. 50.

30 WILLIAM SCHABAS, AN INTRODUCTION TO THE INTERNATIONAL CRIMINAL COURT

(2004), pp. 81. The ICC can only judge individuals who are over eighteen at the time of the committed violation.

${ }^{31}$ Coalition for the International Criminal Court, Security Council, in OfFICIAL WeBSITE

OF THE COALITION FOR THE INTERNATIONAL CRIMINAL COURT (2014), available at

http://www.iccnow.org/?mod=sc $>$.

32 See VAlerio de Oliveira MaZzUOli, TRibunal Penal Internacional e o Direito

BRASILEIRO (2011), pp. 57. 
fact that the UNSC and the ICC have a close relation and that the cases analyzed by one can be a part of the jurisdiction of the other especially in armed conflicts in the international system. The case of Libya, which will be analyzed in the following section, is an example that demonstrates the close link between them.

\section{THE CONFLICT IN LIBYA}

\section{A Historical Overview}

Once the rules and functioning of the ICC have been described, it is essential to present a historical overview of Libya from 1969 to 2011 in order to understand the case that was referred to the Court by the UNSC. The trials of the political leader Muammar al-Gaddafi, his son and Prime Minister Saif Al-Islam Gaddafi and the commandant of the Libyan Army, Abdullah Al-Senussi, represent the fuse point of their illicit behavior during more than forty years. ${ }^{33}$ It is fundamental to understand the characteristics of Libya's government since Gaddafi assumed its presidency.

In 1969, Gaddafi - who was only twenty years old - took the Libyan government after a coup d'état, characterized by its military hallmark that downed King Idris I. France and the United Kingdom, which supported the King, clearly expressed their worries about the new government. Since then, Gaddafi established an anti-Western (and antiNorth American) regime due to his nationalist ideal. He nationalized oil companies and, in 1970, ordered the closure of the USA Wheelus air force base in Tripoli and the United Kingdom air base in Tobruk. Therefore, he adopted a government system very different from the one of King Idris, who created hundreds of pipelines and opened them to the Western powers. From 1973 to 1977, Gaddafi proclaimed both the cultural and the popular revolution owing to his Pan-Arab inspiration. ${ }^{34}$

${ }^{33}$ See International Criminal Court, The Prosecutor v. Saif Al-Islam Gaddafi, in OfFICIAL WEBSITE OF THE INTERNATIONAL CRIMINAL COURT, November, 1, 2011, available at

$<$ http://www.icc-

cpi.int/en menus/icc/situations \%20and \%20cases/situations/icc0111/related $\% 20$ cases/ic c01110111/Pages/icc01110111.aspx>.

${ }^{34}$ Pan-Arabism is the ideology based on the unification of the Arab World, from North Africa to West Asia. The main basis of such ideology is nationalism, meaning an opposition to the Western influence over the countries of the region.

1 JOURNAL OF INSTITUTIONAL STUDIES 1 (2015) 
In 1977, Libva became officially the Great Socialist People's Libyan Arab Jamahiriya. ${ }^{35}$

Libya has always been a strategic region for the West due to its great oil reserves - the countrv is a member of the Organization of the Petroleum Exporting Countries (OPEC). Libva is in an essential geostrategic area in the international svstem because of its position in the Mediterranean Sea that links important oil fields in the region. ${ }^{36}$

In order to understand Libya's social framework, it is important to highlight the division inside the country, which is based on regions inhabited by various ethnic groups. Libya is divided in three areas: Tripolitania, Cyrenaica and Fezzan. The first is located in the Western part of the country and is the place of birth of Gaddafi, which explains the great support he had there. Cyrenaica is in the East and corresponds to the Eastern slope of Libya. The rebels that promoted the riots against Gaddafi's forces since February 2011 were from Cyrenaica. Among the rebels in this area, there were Al-Qaeda members, who were Bin Laden's supporters ${ }^{37}$ Finally, Fezzan is the poorest region of Libya and does not have an active political participation. It is fundamental to comprehend this scenario to know how the country is politically divided and from where the protests came from.

It is unquestionable that Gaddafi's government is dictatorial, since the Libvan Armv constantly suffocated the opposing internal powers. Notwithstanding, during his government, the countrv has the best Human Development Index (HDI) of all Africa. Therefore, Libya, during

${ }_{35}$ See Leonardo Toledo Manzione \& Ricardo de Oliveira Lopes, Revoluções Árabes: o caso da Líbia, 10 Revista GEO-PAISAGEM 19 (2011).

${ }^{36}$ See BBC News, Libya profile - Timeline, in BBC News WEBSITE, February, 16, 2015, available at $<$ http://www.bbc.com/news/world-africa-13755445 $>$.

${ }^{37}$ It is important to highlight the possible contradiction with the fact that Al-Qaeda members helped the rebellion in Libya, for Al-Qaeda is considered as a terrorist group and the rebellion searched for alternatives for Gaddafi's tyranny regime. However, in 2011, Abdel-Hakim Al-Hasidi, the Libyan rebel leader, affirmed that there were fighters that had links with Al-Qaeda amongst the rebels. See Praveen Swami, Libyan rebel commander admits his fighters have Al-Qaeda links, in THE TELEGRAPH, March, 25, 2011, available at <http://www.telegraph.co.uk/news/worldnews/africaandindianocean/libya/8407047/Li byan-rebel-commander-admits-his-fighters-have-al-Qaeda-links.html>. 
Gaddafi's government, presented social stability and, definitely, political instability. ${ }^{38}$

The uprisings in Libya were one of the effects arising from the Arab Spring, the name given by the Western media to the protests that spread across the Middle East and North Africa..$^{39}$ The Arab Spring's trigger in Libya was on 15 February 2011, when Libyan citizens - mainly those from Cyrenaica - took the streets and, inspired by the manifestations that occurred in Tunisia and Egypt, protested against the forty years of Gaddafi's government. The country's leaders reacted that same day by using the Army and violence, causing twenty deaths. The date became known as the "furious day", and its consequence was the mass exit of the population from Benghazi. Before 20 February, the number of deaths was higher than eighty. Gaddafi and his son, Saif Al-Islam, affirmed that they would only leave the country dead, and they believed that the riots were supported by Al-Qaeda. ${ }^{40}$

On 27 February, the opposition tried to take control of Zawiyah, a city located about fifty kilometers from Tripoli, Libya's capital. In return, Gaddafi reaffirmed that he would not leave the government and that most part of the population gave him support. On March, the UN expressed its concern for the seventy thousand refugees who crossed the frontier between Libya and Tunisia. Part of the Libyan Army went to the frontier in order to control such contingence, causing fear in the Libyan people. As a consequence of the violent reactions of Libya's government, the UN unanimously suspended the country from its Human Rights Council. On 12 March, with the exception of Algeria and Syria, the members of the Arab League decided to support the no-fly zone and to establish a direct contact with the National Transitional Council (NTF) of Libya, composed by the rebels who lead the riots in the country. ${ }^{41}$ Therefore, the escalation of tensions between Gaddafi and the Western leaders happened in a context of expansion of the Arab

${ }^{38}$ See Leonardo Toledo Manzione \& Ricardo de Oliveira Lopes, Revoluções Árabes: o caso da Líbia, 10 Revista GeO-PAISAGEM 19 (2011).

${ }^{39}$ In December 2010, the vegetable seller, Tarek Bouazizi, set fire on himself in Tunisia as a form of protesting against Ben Ali's monarchy. This event revolted and shocked the Tunisian population and, in three days, the country was living a social chaos. Such action boosted countless riots in the so-called Arab World.

40 See Leonardo Toledo Manzione \& Ricardo de Oliveira Lopes, Revoluções Árabes: o caso da Líbia, 10 ReVISTA GEO-PAISAGEM 19 (2011).

${ }^{41}$ See Leonardo Toledo Manzione \& Ricardo de Oliveira Lopes, Revoluções Árabes: o caso da Líbia, 10 Revista GEO-PAISAGEM 19 (2011).

1 JOURNAL OF INSTITUTIONAL STUDIES 1 (2015) 
Spring. Since then, the country has been under civil war with different groups struggling for power.

\section{Gaddafi's government, the P-5 and the UNSC}

In order to comprehend the international response to the situation in Libya, it is indispensable to approach the relations of the country with the UNSC, especially with its main powers, the P-5. The strategic positioning of the Libyan territory always attracted the interest of these powers. The country is not only rich in oil reserves - corresponding to two percent of the global production - but is also in a key region of the Mediterranean due to its location next to Egypt and the Suez Canal. Libya is also a link between the North African countries and the Middle East. All these factors are some of the reasons why the P-5 countries have always been present in this African country.

China and Russia have never cut relations with Libya during Gaddafi's government, mainly because of their interest in Libya's oil resources. Russia always sold weapons to Gaddafi's forces and had a huge interest in the geostrategic location of Libya in the Mediterranean Sea. In addition, China has historically had trade interests in the Middle East, including Libya. Before the military coup d'état, in 1969, the Western countries - USA, United Kingdom and France - had benefited from the oil exploration in the Libyan territory. However, Gaddafi finished the privileged relations after 1969 due to his anti-West approach. Since then, the relations among these countries have been tense.

In the 1980s, many events made the situation more difficult, such as the USA attack to Libyan aircrafts in the Gulf of Sirte in 1981. In 1984, it was the turn of the United Kingdom government to also cut diplomatic relations with Libya when a British policewoman was shot in a riot against Gaddafi in the Libyan Embassy in London. But Gaddafi publicly declared his hate for the USA after his daughter's death in 1986, during an American bombing in Tripoli and Benghazi that caused the death of one hundred and one persons. All of these events generated a political reaction by the Arab countries, whose apex was the creation of the Arab Maghreb Union, by Libya, Algeria, Morocco, Mauritania and Tunisia. ${ }^{42}$

${ }^{42}$ See BBC News, Libya profile - Timeline, in BBC NeWs WEBSITE, February, 16, 2015, available at $<$ http://www.bbc.com/news/world-africa-13755445>. 
In the 1990s, the UNSC began to act more directly in Libya. An example is the sanction imposed by the Council in 1992 due to the involvement of two Libyans in a terrorist attack to the PanAm Airlines in 1988. The intention was to exercise control over Gaddafi's government. However, this action endured seven years, until 1997, when the sanction was suspended. In the same year, the United Kingdom government reestablished diplomatic relations with Libya. ${ }^{43}$

In 2002, the president Bush administration also promoted conversations about the normalization of USA-Libya relations. After that, in 2003 and 2004, the other UN members appeared to be willing to maintain contact with the Gaddafi's government: Libya was elected, even against the will of the USA, as chairman of the UN Human Rights Commission. In August, Libya took the responsibility for the Lockerbie bombing that occurred in 1988. Then, Gaddafi's government decided to use diplomacy, abandoning the development of weapons of mass destruction and reopening, after more than 20 years, the exploration of oil resources in the Libyan territory to American corporations. Clearly, those events showed that Libya was reinserted in the concert of the Great Powers after years of tense relations with them. As a result, Libya was in contact with the USA government and, in 2008, it was elected for the rotating presidency of the UNSC.

The turning point of this improved relationship between the West and Libya started in 2010, when the WikiLeaks exposed documents that revealed the eventual cut trade by Gaddafi if the bomber responsible by the Lockerbie case died in prison. It unsettled again the relations between United Kingdom and Libya. Meanwhile, the Russian government made a deal with Gaddafi that was worth US $\$ 1.8$ billion, tantamount to the selling of jets and defense system. ${ }^{44}$

In 2010, due to the rebuild of diplomatic relations between the USA and United Kingdom with Libya, the Arab country did not suffered sanctions from the UNSC. However, owing to the dissemination of the Arab Spring in Libya, there was a violent conflict between the rebels and Gaddafi's forces. The West and NATO alwavs accused Muammar Al-Gaddafi of financing terrorist attacks. In addition, the corruption and

${ }^{43}$ See BBC News, Libya profile - Timeline, in BBC NeWs WeBSITE, February, 16, 2015, available at $<$ http://www.bbc.com/news/world-africa-13755445 $>$.

${ }^{44}$ See BBC News, Libya profile - Timeline, in BBC NeWs WEBSITE, February, 16, 2015, available at $<$ http://www.bbc.com/news/world-africa-13755445 $>$.

1 JOURNAL OF INSTITUTIONAL STUDIES 1 (2015) 
the use of petroleum's monev to expand its weapons capabilities were also a strategy adopted by the Libyan State during Gaddafi's regime..$^{45}$

Gaddafi's behavior before and mainly after the beginning of the Arab Spring was marked by the violent oppression against opposition groups. In this scenario, the UNSC decided to impose Resolution 1970 against both Libya and Muammar Al-Gaddafi. This Resolution was approved on 26 February 2011 and expressed the UN concerns with the violence against civilians in Libya and the massive violations of human rights, as well as the precarious conditions of refugees. An embargo forbidding the selling and buying of arms and all related technologies was declared. It was also decided that Libya "shall cease the export of all arms and related materiel and that all Member States shall prohibit the procurement of such items from the Libyan Arab Jamahiriya by their nationals". ${ }^{46}$ Traveling to Libya was forbidden by the Member States, which should take all measures to discourage their citizens to travel to the Libyan territory. An asset freeze was also one of the decisions of Resolution 1970. It means that all the Member States should freeze "all funds, other financial assets and economic resources" linked to Libya. ${ }^{47}$

Besides the imposition of sanctions that affected the economic and military capabilities of Libya's government, Resolution 1970 also used a legal tool by recalling Article 16 of the Rome Statute to refer the case of Libya to the ICC, which should investigate it within a twelve-month term after the request of the UNSC. On 16 February 2011, therefore, the case was directed to the Prosecutor of ICC.

Following this measure, the UNSC also approved Resolution 1973 on 17 March 2011, which not only reaffirmed the conditions established in Resolution 1970, but also imposed a no-fly zone over Libya: only flights with humanitarian aid would be allowed to fly over such area. In addition, the arms embargo and the asset freeze were enforced, and the

\footnotetext{
45 See BBC News, Libya profile - Timeline, in BBC NEWs WEBSITE, February, 16, 2015, available at $<$ http://www.bbc.com/news/world-africa-13755445 $>$.

46 See United NATIONS SECURITY COUNCIL, RESOlUtION 1970 - AdOPTED BY THE SECURITY COUNCIL AT ITS 6491ST MEETING (S/RES/1970), February, 26, 2011, available at $<$ http://www.un.org/en/ga/search/view doc.asp?symbol=S/RES/1970\%282011\%29>. 47 See United NATIONS SECURITY COUNCIL, RESOLUTION 1970 - ADOPTED BY THE SECURITY COUNCIL AT ITS 6491ST MEETING (S/RES/1970), February, 26, 2011, available at <http://www.un.org/en/ga/search/view doc.asp?symbol=S/RES/1970\%282011\%29>.
} 
Member States were authorized to take all necessary actions in order to protect Libyan civilians. ${ }^{48}$

As Libya is not a part of the Rome Statute, only the referral of the UNSC made in Resolution 1970 could authorize the investigation of the case by the ICC, as stated in the Rome Statute. In addition, all the countries that adopted the Rome Statute shall contribute to the investigations. ${ }^{49}$ Therefore, based on the rules of the Rome Statute, Muammar Al-Gaddafi, Saif Al-Islam Gaddafi and Abdullah Al-Senussi were investigated by the ICC in order to define the admissibility of the case.

\section{NATO's actions}

Besides the actions taken by the UNSC and the ICC, it is crucial to clarify that the situation in Libya is even more complex due to NATO's interventions since 2011. The organization affirms that its actions in the country were necessary to guarantee the protection of the civilians. ${ }^{50}$

On 3 March 2011, NATO's representative assured the world press that an intervention in Libya was not being considered by the organization. However, French airplanes attacked vehicles and Army basis of Gaddafi's forces on 19 March, which was followed by the launching of more than a hundred missiles - ordered by the governments of the USA, Canada, United Kingdom and Italy. The Western countries called this operation Odyssey Dawn. Although pressure from NATO was constant, which can be proved by its attacks to Tripoli and to Benghazi in March, Gaddafi refused to leave the country. He not only stayed in Libya, but also retaliated those attacks by using his loyal Army. He adopted a strong nationalist speech in defense of Libyan's people and its oil reserves. Gaddafi affirmed that he would not allow the Western countries to take the petroleum from Libya. On 31

48 See United NATIONS SECURITY COUNCIL, RESOLUTION 1973 - AdOPTED BY THE SECURITY COUNCIL AT ITS 6498TH MEETING (S/RES/1973), March, 17, 2011, available at $<$ http://www.un.org/en/ga/search/view doc.asp?symbol=S/RES/1973\%282011\%29>.

49 See United NATIONS SECURITY COUNCIL, RESOLUTION 1973 - AdOPTED bY THE SECURITY COUNCIL AT ITS 6498TH MEETING (S/RES/1973), March, 17, 2011, available at $<$ http://www.un.org/en/ga/search/view doc.asp?symbol=S/RES/1973\%282011\%29>. 50 See Jason Pack, Libya is too big to fail, in FOREIGN POLICY, March, 18, 2011, available at $<$ http://foreignpolicy.com/2011/03/18/libya-is-too-big-to-fail/>. 
March, NATO officially became the leader of the operation in Libyan territory, and changed its name from Odyssey Dawn to Unified Protector. ${ }^{51}$

NATO's actions have actually started on 9 March, when its forces extended the surveillance in the Mediterranean by deploying "Airborne Warning and Control Systems (AWACS) aircraft to the area providing round-the-clock observation". ${ }^{52}$ Between 23 and 24 March, ships moved to enforce the UN embargo to Libya. Then, on 31 March, the Commander of the NATO military operation in Libya, Lieutenant General Charles Bouchard, expressed officially the participation of the organization in the Libyan conflicts in a press conference. Since then, NATO assumed the international military command in Libya and established measures to protect civilians by air and by sea.

In April, the civil war situation worsened due to the intensification of NATO's actions. These attacks were a mark in Libva's framework in 2011, since NATO made them directly - by air strikes - or indirectly by financing the rebels. Gaddafi returned to disseminate a hate speech after his son's death - Saif Al-Arab Gaddafi - during a NATO attack on 30 April. From Mav to Iune. Libva definitelv became a war zone. NATO attacks intensified, destroving part of the countrv's infrastructure, mainlv in its capital, Tripoli. It caused the exit of thousands of civilians, who became refugees..$^{53}$

Therefore, the ICC's work in investigating the crimes committed in Libya emerged in a complex situation, in which the escalation of violence involved not only the government and the rebel forces, but also the military intervention of NATO. In this unpredictable scenario, the members of the Court had to follow the rules of the Rome Statute, and also assure that both the UNSC and the States parties would cooperate with the investigations. However, the role of the ICC in the Libyan case and its results were very particular and will be analyzed in the final considerations.

\footnotetext{
${ }^{51}$ See Leonardo Toledo Manzione \& Ricardo de Oliveira Lopes, Revoluções Árabes: o caso da Líbia, 10 REVISTA GEO-PAISAGEM 19 (2011).

52 See North Atlantic Treaty Organization, NATO and Libya: Operation Unified Protector, in OfFicial Website Of THE North Atlantic Treaty OrGanization, March, 27, 2012, available at $<$ http://www.nato.int/cps/en/natolive/71679.html $>$.

${ }^{53}$ See Rogério Duarte Fernando dos Passos, Uma crônica: Primavera Árabe, Líbia e Ocidente, Organização do Tratado do Atlântico Norte, um advogado francês e Tribunal Penal Internacional, 11 CADERNOS DE DIREITO 21 (2011), available at $<$ https://www.metodista.br/revistas/revistasunimep/index.php/direito/article/viewArticle/971>.
} 


\section{FinAl CONSIDERATIONS}

The UNSC decided on 26 February 2011, with 15 votes in favor, that the ICC would be the instance to judge the crimes committed in Libya by some of its specific previous authorities. The ICC Prosecutor, therefore, would be responsible for conducting preliminary observance of the situation in the country and analyzing if crimes that could be judged by the ICC were really committed. The Prosecutor, after this phase, concluded on 3 March 2011 that there were several reasons to believe that the crimes under the ICC's jurisdiction had in fact been committed in Libya and an investigation was finally opened. ${ }^{54}$

After that, on 16 May 2011, the Prosecutor requested the issuance of warrants of arrest for Muammar Al-Gaddafi, Saif Al-Islam Gaddafi and Abdullah Al-Senussi for their crimes committed in the Libyan territory and that were under the ICC's jurisdiction. And, after the analyses of the request, the Pre-Trial Chamber I granted the Prosecutor's request and issued the warrants arrest on 27 June 2011.

The judgment process was finally beginning to happen. However, the arrest warrant against Muammar Al-Gaddafi was withdraw on 22 November 2011, for the former leader of Libya was killed on 20 October 2011 in the city of Sirte, where he had been taking shelter: "the exact circumstances of his death remain in dispute, either 'killed in crossfire', summarily executed, or lynched and dragged through the streets by jubilant, battle-hardened fighters".$^{55}$

His judgment, therefore, was impossible to be carried out by the ICC. But the warrants of arrest for Saif Al-Islam Gaddafi and Abdullah Al-Senussi were still in the order of the day. Nevertheless, on 1 May 2012, "the government of Libya challenged the admissibility of the case concerning Saif Al-Islam Gaddafi before the Pre-Trial Chamber I". ${ }^{6}$ The Court, in its Pre-Trial Chamber I, considered that there were

${ }^{54}$ See International Criminal Court, Situation in Libya: The Prosecutor v. Saif Al-Islam Gaddafi, in OFFICIAL WEBSITE OF THE INTERNATIONAL CRIMINAL COURT (2015), available at $<$ https://www.icc-cpi.int/iccdocs/PIDS/publications/GaddafiEng.pdf $>$.

55 Martin Asser, The Muammar Gaddafi story, in BBC NEWS WeBSITE, October, 21, 2011, available at $<$ http://www.bbc.com/news/world-africa-12688033 $>$.

${ }^{56}$ See International Criminal Court, Situation in Libya: The Prosecutor v. Saif Al-Islam Gaddafi, in OFFICIAL WEbSITE OF THE INTERNATIONAL CRIMINAL COURT (2015), available at $<$ https://www.icc-cpi.int/iccdocs/PIDS/publications/GaddafiEng.pdf $>$.

1 JOURNAL OF INSTITUTIONAL STUDIES 1 (2015) 
"reasonable grounds to believe that, under Article 23 (3)(a) of the Rome Statute, Saif Al-Islam Gaddafi is criminally responsible as indirect coperpetrator of two counts of crimes against humanity" 57 , which were murder and persecution.

But the challenge to the admissibility was a fact that would have to be discussed in the ICC, for the Court was created under the principle of complementarity of national criminal justice systems. Therefore, the ICC can not replace a national instance that is willing to judge a case, but only complement it: "the ICC can investigate and, where warranted, prosecute and try individuals only if the State concerned does not, cannot or is unwilling genuinely to do so" ${ }^{58}$ Apparently, this was not the case.

The Pre-Trial Chamber I concluded on 31 May 2013 that Libya was not able to properly carry out the prosecution of Saif Al-Islam Gaddafi and, therefore, rejected the challenge to the admissibility. They also stated "that the evidence submitted was not sufficient to consider that the domestic and the ICC investigations cover the same case". ${ }^{59}$ Besides, "on 21 May 2014, the ICC Appeals Chamber confirmed the decision of Pre-Trial Chamber I declaring the case against Saif Al-Islam Gaddafi admissible". ${ }^{60}$ Therefore, the ICC would be able to prosecute Saif AlIslam from that day on.

Possibly not satisfied with the results, the Libyan authorities carried out another challenge to the admissibility on 2 April 2013, but this time regarding the case of Abdullah Al-Senussi. On 11 October 2013, the PreTrial Chamber I came to the conclusion that the ICC could not continue with the case against Al-Senussi due to the fact that he was at the same time subject to domestic legal proceedings of Libya's internal justice system. Therefore, the 24 July 2014 the ICC's Appeals Chambers

${ }^{57}$ See International Criminal Court, Situation in Libya: The Prosecutor v. Saif Al-Islam Gaddafi, in OfFICIAL Website OF THE INTERNATIONAL CRIMINAL COURT (2015), available at $<$ https://www.icc-cpi.int/iccdocs/PIDS/publications/GaddafiEng.pdf $>$.

58 See International Criminal Court, Situation in Libya: The Prosecutor v. Saif Al-Islam Gaddafi, in OfFICIAL WEBSITE OF THE INTERNATIONAL CRIMINAL COURT (2015), available at $<$ https://www.icc-cpi.int/iccdocs/PIDS/publications/GaddafiEng.pdf $>$.

59 See International Criminal Court, Situation in Libya: The Prosecutor v. Saif Al-Islam Gaddafi, in OfFICIAL WEBSITE OF THE INTERNATIONAL CRIMINAL COURT (2015), available at $<$ https://www.icc-cpi.int/iccdocs/PIDS/publications/GaddafiEng.pdf $>$.

${ }^{60}$ See International Criminal Court, Situation in Libya: The Prosecutor v. Saif Al-Islam Gaddafi, in OfFICIAL WebSite OF THE INTERNATIONAL CRIMINAL COURT (2015), available at $<$ https://www.icc-cpi.int/iccdocs/PIDS/publications/GaddafiEng.pdf $>$. 
confirmed the previous decision made by the Pre-Trial Chamber I: the case of Abdullah Al-Senussi was inadmissible before the ICC jurisdiction. From that moment on, "proceedings against Abdullah AlSenussi before the Court hence came to an end". ${ }^{61}$

It is possible to observe after the events that took place recently that the role of the ICC in the Libyan case, regarding the possibility of trial of Muammar Al-Gaddafi, Saif Al-Islam Gaddafi and Abdullah Al-Senussi, was not fulfilled due especially to certain legal mechanisms. Nevertheless, a court in Tripoli sentenced Saif Al-Islam Gaddafi and Abdullah Al-Senussi to death alongside eight ancient Libyan authorities of Gaddafi's regime. ${ }^{62}$ However, "there is uncertainty about whether the sentence will be carried out, as Gaddafi is being held by a militia in the mountain town of Zintan that is opposed to Libya Dawn, the militia coalition in control of Tripoli". ${ }^{63}$

Saif Al-Islam Gaddafi has been held prisoner since he tried to flee from Libya in 2011 by a militia group that rejects the coalition who is in control of the capital of Libya, where the process against Gaddafi was carried out since April 2014; except from Saif Al-Islam Gaddafi, all other condemned are in judicial custody. Moreover, even if the authorities had concluded the case in Tripoli and condemned Saif Al-Islam Gaddafi and Abdullah Al-Senussi, amongst others, to death, there is still a lot of controversial going on in the international community about the outcome of the case.

The struggle for power in Libya has been part of contemporaneity politics especially with the civil war that caused many internal displacements and with the constant threat of the Islamic State, which has initiated an even more complex situation in the region and invaded parts of Libya. However, the Libyan army and the Tripoli militia had declared on January 2015 a partial ceasefire, a process that counted with the UN Secretary-General Ban Ki-moon visits and talks with the recent

${ }^{61}$ See International Criminal Court, Situation in Libya: The Prosecutor v. Saif Al-Islam Gaddafi, in OFFICIAL WEBSITE OF THE INTERNATIONAL CRIMINAL COURT (2015), available at $<$ https://www.icc-cpi.int/iccdocs/PIDS/publications/GaddafiEng.pdf $>$.

62 See Chris Stephen, Saif Al-Islam sentenced to death by court in Libya, in THE GUARDIAN, July, 28, 2015, available at $<$ http://www.theguardian.com/world/2015/jul/28/saif-alislam-sentenced-death-by-court-in-libya-gaddafi-son>.

${ }^{63}$ See Chris Stephen, Saif Al-Islam sentenced to death by court in Libya, in THE GUARDIAN, July, 28, 2015, available at $<$ http://www.theguardian.com/world/2015/jul/28/saif-alislam-sentenced-death-by-court-in-libya-gaddafi-son>.

1 JOURNAL OF INSTITUTIONAL STUDIES 1 (2015) 
Libyan parliament, the authorities and the militia that is holding Tripoli, the Libya Dawn. ${ }^{64}$

This general scenario, however, did not prevent the trials from happening in the Libyan territory. The questioning about the legal proceedings has raised especially from the advocates of Saif Al-Islam Gaddafi and Abdullah Al-Senussi. Ben Emmerson, Al-Senussi's lawyer, had declared that death sentenced issued by the Libyan court is difficult to be accepted and that it was formed in an atmosphere of fear. Besides, Al-Senusi "had no legal representation, no access to his family, no ability to prepare his defense and no possibility of challenging the prosecution". .55

John Jones, Saif Al-Islam Gaddafi's ICC appointed lawyer, also condemned the trial process made in Libya by saying that it was a farce and run by Libya Dawn militias. ${ }^{66}$ They were not the only ones to question the situation in Libya: the Amnesty International, the International Bar Association and the Human Rights Watch issued statements condemning the whole process, as well as the ICC. This fact leads us to the question: would the aftermath be different if the ICC had been able to continue the prosecution of these individuals?

The questioning that arose with the situation started first of all with the decision of Libyan authorities not to fulfill the warrants of arrest issued by the ICC in 2011. At the same time, ICC did not have the power to enforce the decision. The principle of complementarity that bases the Court could be understood as an obstacle in the specific case of Saif AlIslam Gaddafi and Abdullah Al-Senussi, who "wanted to be tried by the ICC - they were keen to avoid the death penalty (which the ICC cannot issue) and argued they would not get a fair trial in Libya" ${ }^{67}$ Therefore, if ICC had been able to continue with the judgment of the cases, it is

${ }^{64}$ See BBC News, Libya profile - Timeline, in BBC News WeBSITE, February, 16, 2015, available at $<$ http://www.bbc.com/news/world-africa-13755445 $>$.

65 See Robert Fisk, Abdullah Al-Senussi execution: this pervesion of justice suits Western security services just fine, in THE INDEPENDENT, August, 3, 2015, available at

$<$ http://www.independent.co.uk/voices/abdullah-al-senussi-execution-this-perversionof-justice-suits-western-security-services-just-fine-10433785.html>.

${ }^{66}$ See Chris Stephen, Saif Al-Islam sentenced to death by court in Libya, in THE GUARDIAN, July, 28, 2015, available at <http://www.theguardian.com/world/2015/jul/28/saif-alislam-sentenced-death-by-court-in-libya-gaddafi-son>.

${ }^{67}$ See Yvone McDermott, How Libya became the International Criminal Court's latest failure, in THE CONVERSATION, August, 6, 2015, available at $<$ http://theconversation.com/howlibya-became-the-international-criminal-courts-latest-failure-45389>. 
possible to say that they would have been different and would definitely not end with the death penalty.

Nevertheless, the handling of the situation in the recent years demonstrated that ICC had a primary role to fulfill in these cases, but that the result was a demonstration of the ICC's limits. As Libya did not honored the warrants of arrest and challenged the ICC jurisdiction over the cases, the ICC was not able to fulfill its core objective: judging persons for the most serious crimes committed in the international system. Libya has not signed nor ratified the Rome Statute and referred the matter of the requests to the UNSC, which "did call upon Libya to cooperate with the Court in May 2015, but in vague terms and without explicit mention of Saif Gaddafi's transfer"68, who was to be judged in The Hague according to ICC's previous ruling.

The ICC has gained exponential importance in the international system since its creation: its main role of investigation and trial of the gravest crimes committed is essential "to help end impunity for the perpetrators of the most serious crimes of concern to the international community". ${ }^{69}$ Taking into consideration everything that was presented above, it is possible to consider that the ICC not only encompasses an international jurisdictional system, but is also a stage of constant struggle for power amongst nations. The cases judged by the Court are crucial to the relations in the international system and the decisions adopted have a profound impact in the paths of conflicts and in the effectiveness of the UN system of human rights.

The panorama after the trials hold in Libya and the fact that the ICC was powerless to carry out the cases shows that the Court "lacks an independent enforcement mechanism and relies entirely on State cooperation $(\ldots)^{\prime \prime} . .^{70}$ This is not a problem per se, but considering the power that the UNSC has over the Court, is evident that divergences may arise in the processes and therefore the ICC jurisdiction can be delimited over time. But if one thing can be said for sure is that the

\footnotetext{
${ }^{68}$ See Yvone McDermott, How Libya became the International Criminal Court's latest failure, in THE CONVERSATION, August, 6, 2015, available at $<$ http://theconversation.com/howlibya-became-the-international-criminal-courts-latest-failure-45389>.

${ }^{69}$ See International Criminal Court, About the Court, in OfFICIAL WEBSITE OF THE INTERNATIONAL CRIMINAL COURT (2014), available at $<$ http://www.icccpi.int/en menus/icc/about\%20the\%20court/Pages/about\%20the\%20court.aspx>. ${ }^{70}$ See Yvone McDermott, How Libya became the International Criminal Court's latest failure, in THE CONVERSATION, August, 6, 2015, available at $<$ http://theconversation.com/howlibya-became-the-international-criminal-courts-latest-failure-45389>.
}

1 JOURNAL OF INSTITUTIONAL STUDIES 1 (2015) 
ICC's prestige suffered a heavy blow with its incapability to handle with the cases of Saif Al-Islam Gaddafi and Abdullah Al-Senussi. ${ }^{71}$

\section{REFERENCES}

BBC News, Libya profile - Timeline, in BBC NeWs WEBSITE, February, 16, 2015, available at $<$ http://www.bbc.com/news/world-africa-13755445 $>$.

Chris Stephen, Saif Al-Islam sentenced to death by court in Libya, in THE GUARDIAN, July, 28, 2015, available at $<$ http://www.theguardian.com/world/2015/jul/28/saif-al-islamsentenced-death-by-court-in-libya-gaddafi-son>.

Claire Tisserant, Victims' participation at the International Criminal Court (ICC): the growing role of their legal representatives, in INTERNATIONAL JuSTICE PROJECT, August, 8, 2013, available at $<$ http://www.internationaljusticeproject.com/victims-participation-atthe-international-criminal-court-icc-the-growing-role-of-their-legalrepresentatives/>.

Coalition for the International Criminal Court, Security Council, in OFFICIAL WEBSITE OF THE COALITION FOR THE INTERNATIONAL CRIMINAL COURT (2014), available at http://www.iccnow.org/?mod=sc>.

Elio Cardoso, Tribunal Penal Internacional: Conceitos, ReAlidades E IMPLICAÇÕES PARA O BRASIL (2012).

International Criminal Court, About the Court, in OfFICIAL WEBSITE OF THE INTERNATIONAL CRIMINAL COURT (2014), available at $<\underline{\mathrm{http}: / / w w w . i c c-}$

${ }^{71}$ See Chris Stephen, Saif Al-Islam sentenced to death by court in Libya, in THE GUARDIAN, July, 28, 2015, available at $<$ http://www.theguardian.com/world/2015/jul/28/saif-alislam-sentenced-death-by-court-in-libya-gaddafi-son>. 
cpi.int/en menus/icc/about $\% 20$ the $\% 20$ court/Pages/about $\% 20$ the $\% 20$ cou rt.aspx>.

International Criminal Court, Chambers, in OfFICIAL WEBSITE OF THE INTERNATIONAL CRIMINAL COURT (2014), available at $<$ http://www.icccpi.int/en menus/icc/structure\%20of\%20the\%20court/chambers/Pages/c hambers.aspx>.

International Criminal Court, Defence, in OfFICIAL WEBsite OF THE INTERNATIONAL CRIMINAL COURT (2014), available at $<\underline{\mathrm{http}: / / w w w . i c c-}$ cpi.int/en menus/icc/structure\%20of\%20the\%20court/defence/Pages/def ence.aspx>.

International Criminal Court, Legal Representatives of Victims, in OFFICIAL WEBSITE OF THE INTERNATIONAL CRIMINAL COURT (2014), available at $<$ http://www.icccpi.int/en menus/icc/structure $\% 20$ of $\% 20$ the $\% 20$ court/victims/legal $\% 20 \mathrm{r}$ epresentation/Pages/legal\%20representatives $\% 20$ of $\% 20$ victims.aspx>.

International Criminal Court, Office of the Prosecutor, in OfFICIAL WeBsite OF THE INTERNATIONAL CRIMINAL COURT (2014), available at $<\underline{\text { http://www.icc- }}$ cpi.int/en menus/icc/structure $\% 20$ of $\% 20$ the $\% 20$ court/office $\% 20$ of $\% 20$ th e\%20prosecutor/Pages/office\%20of\%20the\%20prosecutor.aspx>.

International Criminal Court, Rome Statute of the International Criminal Court, in OfFicial Website of THE INTERNATIONAL CRIMINAL COURT (2014), pp. 3, available at http://www.icccpi.int/NR/rdonlyres/ADD16852-AEE9-4757-ABE79CDC7CF02886/283503/RomeStatutEng1.pdf>.

International Criminal Court, Situation in Libya: The Prosecutor v. Saif AlIslam Gaddafi, in OfFICIAL WEBSITE OF THE INTERNATIONAL CRIMINAL 
COURT (2015), available at $<$ https://www.icccpi.int/iccdocs/PIDS/publications/GaddafiEng.pdf > .

International Criminal Court, Structure of the Court, in OfFICIAL WEBSITE OF THE INTERNATIONAL CRIMINAL COURT (2014), available at $<$ http://www.icccpi.int/en menus/icc/structure $\% 20$ of $\% 20$ the $\% 20$ court/Pages/structure $\% 2$ 0of\%20the\%20court.aspx>.

International Criminal Court, The Prosecutor v. Saif Al-Islam Gaddafi, in OfFicial WEbSite Of the INTERNATIONAL CRIMINAL COURT, November, 1, 2011, available at $<$ http://www.icccpi.int/en menus/icc/situations\%20and\%20cases/situations/icc0111/relat ed\%20cases/icc01110111/Pages/icc01110111.aspx>.

Jason Pack, Libya is too big to fail, in ForeIGN POLICY, March, 18, 2011, available at $<$ http://foreignpolicy.com/2011/03/18/libya-is-too-big-to-fail/>.

Leonardo Toledo Manzione \& Ricardo de Oliveira Lopes, Revoluções Árabes: o caso da Líbia, 10 Revista GEO-PAISAGEM 19 (2011).

Martin Asser, The Muammar Gaddafi story, in BBC News WEBSITE, October, 21, 2011, available at $<$ http://www.bbc.com/news/world-africa$\underline{12688033}>$.

North Atlantic Treaty Organization, NATO and Libya: Operation Unified Protector, in OfFicial Website of the NORTH ATLANTIC TREATY

ORGANIZATION, March, 27, 2012, available at $<$ http://www.nato.int/cps/en/natolive/71679.html $>$.

Praveen Swami, Libyan rebel commander admits his fighters have Al-Qaeda links, in THE TELEGRAPH, March, 25, 2011, available at $<$ http://www.telegraph.co.uk/news/worldnews/africaandindianocean/li 
bya/8407047/Libyan-rebel-commander-admits-his-fighters-have-alQaeda-links.html>.

Robert Fisk, Abdullah Al-Senussi execution: this pervesion of justice suits Western security services just fine, in THE INDEPENDENT, August, 3, 2015, available at $<\underline{\mathrm{http}}$ ://www.independent.co.uk/voices/abdullah-al-senussiexecution-this-perversion-of-justice-suits-western-security-services-justfine-10433785.html .

Rogério Duarte Fernando dos Passos, Uma crônica: Primavera Árabe, Líbia e Ocidente, Organização do Tratado do Atlântico Norte, um advogado francês e Tribunal Penal Internacional, 11 CADERNOS DE DIREITO 21 (2011), available at $<$ https://www.metodista.br/revistas/revistasunimep/index.php/direito/article/viewArticle/971>.

United NATIONS SECURITY COUNCIL, RESOLUTION 1970 - AdOPTED By THE SECURITY COUNCIL AT ITS 6491ST MEETING (S/RES/1970), February, 26, 2011, available at $<\underline{\text { http://www.un.org/en/ga/search/view doc.asp?symbol=S/RES/1970\%2 }}$ $\underline{82011 \% 29>}$.

United NATIONS SECURITY COUNCIL, RESOLUTION 1973 - AdOPTED bY THE SECURITY COUNCIL AT ITS 6498TH MEETING (S/RES/1973), March, 17, 2011, available at $<\underline{\text { http://www.un.org/en/ga/search/view doc.asp?symbol=S/RES/1973\%2 }}$ $\underline{82011 \% 29>}$.

Valerio de Oliveira Mazzuoli, Tribunal Penal Internacional e o DiREITO BRASILEIRO (2011).

WILLIAM SCHABAS, AN INTRODUCTION TO THE INTERNATIONAL CRIMINAL COURT (2004). 
Yvone McDermott, How Libya became the International Criminal Court's latest failure, in THE CONVERSATION, August, 6, 2015, available at $<$ http://theconversation.com/how-libya-became-the-internationalcriminal-courts-latest-failure-45389>.

The International Criminal Court and the Cases of Muammar Al-Gaddafi, Saif Al-Islam Gaddafi and Abdullah Al-Senussi O Tribunal Penal Internacional e os Casos de Muammar Al-Gaddafi, Saif Al-Islam Gaddafi e Abdullah Al-Senussi Submitted: 2015-12-10 Accepted: 2016-01-18 